\title{
Effect of quebracho-chestnut tannin extracts at 2 dietary crude protein levels on performance, rumen fermentation, and nitrogen partitioning in dairy cows
}

\author{
M. J. Aguerre, ${ }^{*}$ M. C. Capozzolo,† P. Lencioni, $\ddagger$ C. Cabral, $\ddagger$ and M. A. Wattiaux* \\ *Department of Dairy Science, University of Wisconsin, Madison 53706 \\ †Estación Experimental INTA Reconquista, Reconquista, Argentina 3567 \\ ‡Silvateam, Indunor S. A., Argentina 1010
}

\section{ABSTRACT}

Our objective was to determine the effects of a tannin mixture extract on lactating cow performance, rumen fermentation, and $\mathrm{N}$ partitioning, and whether responses were affected by dietary crude protein (CP). The experiment was conducted as a split-plot with 24 Holstein cows (mean \pm standard deviation; $669 \pm 55$ $\mathrm{kg}$ of body weight; $87 \pm 36 \mathrm{~d}$ in milk; 8 ruminally cannulated) randomly assigned to a diet of [dry matter (DM) basis] 15.3 or $16.6 \% \mathrm{CP}$ (whole plot) and 0 , $0.45,0.90$, or $1.80 \%$ of a tannin mixture in three $4 \times 4$ Latin squares within each level of CP (sub-plot). Tannin extract mixture was from quebracho and chestnut trees (2:1 ratio). Dietary CP level did not influence responses to tannin supplementation. A linear decrease in DM intake (25.5 to $23.4 \mathrm{~kg} / \mathrm{d}$ ) was found, as well as a linear increase in milk/DM intake (1.62 to 1.75$)$ and a trend for a linear decrease in fat-and-protein-corrected milk (38.4 to $37.1 \mathrm{~kg} / \mathrm{d}$ ) with increasing levels of tannin supplementation. In addition, there was a negative linear effect for milk urea $\mathrm{N}$ (14.0 to $12.9 \mathrm{mg} / \mathrm{dL})$, milk protein yield (1.20 to $1.15 \mathrm{~kg}$ ), and concentration (2.87 to $2.83 \%$ ). Furthermore, the change in milk protein concentration tended to be quadratic, and predicted maximum was $2.89 \%$ for a tannin mixture fed at $0.47 \%$ of dietary DM. Tannin supplementation reduced ruminal $\mathrm{NH}_{3}-\mathrm{N}$ (11.3 to $8.8 \mathrm{mg} / \mathrm{dL}$ ), total branched-chain volatile fatty acid concentration $(2.97$ to $2.47 \mathrm{~mol} / 100$ mol), DM, organic matter, CP, and neutral detergent fiber digestibility. Dietary tannin had no effect on intake $\mathrm{N}(587 \pm 63 \mathrm{~g} / \mathrm{d})$, milk N $(175 \pm 32 \mathrm{~g} / \mathrm{d})$, or $\mathrm{N}$ utilization efficiency $(29.7 \pm 4.4 \%)$. However, feeding tannin extracts linearly increased fecal $\mathrm{N}$ excretion (214 to $256 \mathrm{~g} / \mathrm{d}$ ), but reduced urinary N (213 to 177 $\mathrm{g} / \mathrm{d}$ ) and urinary urea $\mathrm{N}$ (141 to $116 \mathrm{~g} / \mathrm{d}$ ) excretion. Decreasing dietary $\mathrm{CP}$ did not influence milk production, but increased $\mathrm{N}$ utilization efficiency (milk N/N

Received December 10, 2015.

Accepted February 18, 2016.

${ }^{1}$ Corresponding author: wattiaux@wisc.edu intake; 0.27 to 0.33$)$, and decreased milk urea $\mathrm{N}$ (15.4 to $11.8 \mathrm{mg} / \mathrm{dL}$ ), ruminal $\mathrm{NH}_{3}-\mathrm{N}$ (11.0 to $9.3 \mathrm{mg} / \mathrm{dL}$ ), apparent digestibility of DM (66.1 to $62.6 \%$ ), organic matter (68.2 to $64.3 \%$ ), and CP (62.9 to $55.9 \%$ ), as well as urinary $\mathrm{N}$ excretion (168 vs. $232 \mathrm{~g} / \mathrm{d}$ ). Results of this study indicated beneficial effects of $0.45 \%$ tannin extract in the diet on milk protein content. Increasing tannin extract levels in the diet lowered urinary $\mathrm{N}$ excretion, but had detrimental effects on DM intake, milk protein content, milk protein yield, and nutrient digestibility.

Key words: quebracho and chestnut tannins, nitrogen, protein, dairy

\section{INTRODUCTION}

Tannins are naturally occurring plant polyphenols with multiple phenolic hydroxyl groups that may form complexes with proteins, metal ions, AA, and polysaccharides (Makkar, 2003). They are broadly classified into hydrolysable (polyphenolic units esterified to a carbohydrate core) and condensed tannins (polymers of covalently bonded flavonols). Hydrolysable tannins and condensed tannins may have both adverse and beneficial effects on animal performance depending on their concentration, chemical structure, and the physiological state of the animal and composition of the diet (Makkar, 2003).

Tannins have the capacity to bind protein through hydrogen bonds forming a tannin-protein complex that is stable in the rumen ( $\mathrm{pH} 5.0$ to 7.0) and resistant to rumen microbial degradation but dissociated in the low $\mathrm{pH}$ environment of the abomasum (Makkar, 2003). Thus, tannins can reduce the amount of protein that is digested in the rumen and increase the flow of protein to the small intestine. Conversely, tannins may reduce nutrient digestibility by inhibiting digestive enzyme and rumen microbial activity (Makkar, 2003). Dose-response studies investigating effects of tannin extracts on animal performance, nutrient utilization efficiency, and $\mathrm{N}$ partitioning in lactating dairy cows are scarce. Furthermore, to the best of our knowledge, 
no studies have evaluated the effects of a combination of condensed and hydrolysable tannins and their possible interactions with dietary $\mathrm{CP}$ level in lactating dairy cows. For example, tannins may not affect protein digestion when fed at low levels and diets have excess protein. However, when dietary protein is close or below requirements, tannins may be detrimental for animal performance (Waghorn, 2008).

Dschaak et al. (2011) reported a decrease in DMI, but no change in digestibility, milk production, and ruminal fermentation when cows were fed quebracho tree (Schinopsis spp.) extracts at 3\% of diet DM. However, Ahnert et al. (2015) observed a reduction in apparent total-tract nutrient digestibility when quebracho extracts were fed at 4 and $6 \%$ of diet DM but not when fed between 1 and $2 \%$ of dietary DM to growing dairy heifers. Sliwinski et al. (2004) and Liu et al. (2013) reported no effect of chestnut tree (Castanea sativa) extracts on DMI and milk production when fed at either 0.49 or $1 \%$ of diet DM. Previous studies have also shown that tannin extracts obtained from quebracho (Dawson et al., 1999; Komolong et al., 2001) or chestnut (Sliwinski et al., 2004) can decrease urinary $\mathrm{N}$ excretion. Ammonia emission from manure is highly correlated with urinary urea $\mathrm{N}$ excretion (Aguerre et al., 2010), which is most vulnerable to volatilization after conversion to $\mathrm{NH}_{3}$ on the barn floor (Muck and Richards, 1983). Thus, a tannin mix from quebracho (condensed tannin) and chestnut tree extracts (hydrolysable tannins) fed at a level that does not compromise animal performance might be used as a dietary strategy to reduce excretion of environmental labile urinary $\mathrm{N}$ in manure.

Thus the first hypothesis evaluated in this trial was that dietary supplementation of a mixture of quebracho and chestnut tannin extracts has no effect on animal performance, digestibility, and rumen function but it reduces excretion of environmental labile urinary $\mathrm{N}$. The second hypothesis stated that the effect of tannin supplementation is influenced by dietary CP level. Thus, our main objective was to determine the dose response to 4 levels of a tannin mix extract fed at 2 levels of dietary $\mathrm{CP}$ on lactating cow performance, nutrient digestibility, rumen parameters, and urinary $\mathrm{N}$ excretion.

\section{MATERIALS AND METHODS}

\section{Animals and Treatments}

The experiment was conducted as a split-plot with 2 levels of dietary $\mathrm{CP}$ evaluated in a complete randomized design (whole plot) and 4 levels of tannin extract evaluated within each level of dietary $\mathrm{CP}$ in three 4 $\times 4$ Latin squares (sub-plot). Twenty-four multiparous lactating Holstein cows (mean $\pm \mathrm{SD} ; 669 \pm 55 \mathrm{~kg}$ of BW; $87 \pm 36$ DIM) were first randomly assigned to 1 of 2 dietary treatments of either 15.3 or $16.6 \% \mathrm{CP}$ on a DM basis. A 1.3-percentage-unit difference between dietary CP levels was achieved by substituting soybean meal and expeller soybean meal for ground corn in a custom-made concentrate mix (Table 1). The 12 cows in each dietary CP level were then randomly assigned to 1 of 4 dietary treatments including $0,0.45,0.90$, or $1.80 \%$ (DM basis) of a tannin extract from quebracho and chestnut trees. One of the 3 Latin squares within each CP level included ruminally cannulated cows.

The tannin extract (Bypro; Silvateam, Indunor S.A., Argentina) contained (by weight) one-third chestnut tannin extract and two-thirds quebracho tannin extract. Quebracho and chestnut extracts were separately analyzed by matrix-assisted laser desorption/ionization time of flight (MALDI-TOF) mass spectrometry according to Pizzi et al. (2009). Analysis by MALDITOF of the quebracho extract indicated the following composition (DM basis): 84.3\% condensed flavan-3-ols (predominantly profisetinidin), $10.7 \%$ oligomers of flavan-3-ols (catechin and epicatechin dimers), and 5\% carbohydrate derivate (dimers of pentose, monocarboxylic acid of hexose, and 6-carbon sugars). The MALDITOF chestnut extract analysis indicated the following composition (DM basis): $7.9 \%$ digalloyl glucose, $5.0 \%$ trigalloyl glucose, $16.5 \%$ pentagalloyl glucose, and $70.6 \%$ oligomers of digalloyl glucose, trigalloyl glucose, and pentagalloyl glucose. A more detailed description of the chestnut extract structure has been reported by Pizzi et al. (2009). Rice hulls were replaced proportionally to the tannin included in the diet (Table 2). Diets were offered as TMR once daily at $0700 \mathrm{~h}$ allowing for 5 to $10 \%$ orts. Ingredient mix was adjusted based on weekly forage DM analysis. Treatment sequences within Latin square were balanced for carryover effects in subsequent periods. Each period lasted $21 \mathrm{~d}$ and consisted of $14 \mathrm{~d}$ for diet adaptation and $7 \mathrm{~d}$ for data and sample collection.

Cows were housed in tie-stall barns bedded on rubber mats with wood shavings as bedding and had free access to water throughout the experiment. Care and handling of the animals was conducted as outlined in the guidelines of the University of Wisconsin College of Agricultural and Life Sciences Animal Care and Use Committee.

\section{Feed and Milk Sampling and Analyses}

Samples of silages, premixes, and cottonseed were collected on the last day of each period and stored at $-20^{\circ} \mathrm{C}$. Total mixed ration and orts samples were col- 
Table 1. Chemical composition (\% of DM unless otherwise noted) of dietary ingredients ${ }^{1}$

\begin{tabular}{lrrcrr}
\hline Item & AS & CS & Premix low & Premix high & \\
\hline DM, $\%$ & 37.5 & 33.8 & 91.3 & 90.2 & 93.1 \\
Ash & 5.8 & 4.7 & 4.3 & 4.5 & 4.3 \\
CP & 19.5 & 6.6 & 17.0 & 20.1 & 21.9 \\
NDF & 43.7 & 39.5 & 13.6 & 15.5 & 42.0 \\
NFC & 28.8 & 46.0 & 58.6 & 54.4 & 12.2 \\
Starch & 0.7 & 32.0 & 41.2 & 34.5 & 0.4 \\
IVDMD $_{30}{ }^{5}$ & 86.1 & 80.4 & - & - & - \\
NDFD $_{30}, \%$ of NDF & 64.4 & 46.5 & - & - & - \\
\hline
\end{tabular}

${ }^{1} \mathrm{AS}=$ alfalfa silage; $\mathrm{CS}=$ corn silage; $\mathrm{CTS}=$ cottonseed.

${ }^{2}$ Ingredient composition (DM basis) for premix low: ground corn $56.7 \%$, solvent soybean meal $11.5 \%$, SoyPass $7.9 \%$ (LignoTech USA Inc., Rothschild, WI), roasted soybeans $8.8 \%$, soy hulls $8.8 \%$, calcium carbonate $1.8 \%$, sodium bicarbonate $1.8 \%$, magnesium oxide $0.4 \%$, dicalcium phosphate $0.4 \%$, Dynamate $0.2 \%$ (The Mosaic Co., Plymouth, MN), salt $1.1 \%$, vitamins $0.6 \%$.

${ }^{3}$ Ingredient composition (DM basis) for premix high: ground corn $50.7 \%$, solvent soybean meal $25.3 \%$, roasted soybeans $8.8 \%$, soy hulls $8.8 \%$, calcium carbonate $1.8 \%$ sodium bicarbonate $1.8 \%$, magnesium oxide $0.4 \%$, dicalcium phosphate $0.4 \%$, Dynamate $0.2 \%$ (The Mosaic Co.), salt 1.1\%, vitamins $0.6 \%$.

${ }^{4} \mathrm{NFC}=100-(\% \mathrm{NDF}+\% \mathrm{CP}+\%$ ether extract $+\%$ ash $)$, using NRC (2001) tabular values for ether extract.

${ }^{5}$ Dairyland Laboratories Inc. (Arcadia, WI). IVDMD ${ }_{30}=30$-h in vitro ruminal NDF DM digestibility; NDFD ${ }_{30}$ $=30-\mathrm{h}$ in vitro ruminal NDF digestibility.

lected the last $3 \mathrm{~d}$ of each period and stored at $-20^{\circ} \mathrm{C}$. Individual feed samples were dried at $60^{\circ} \mathrm{C}$ (forced-air oven) for $48 \mathrm{~h}$ and ground to pass a 1-mm Wiley mill screen (Arthur H. Thomas, Philadelphia, PA). Average DMI was computed over the last $7 \mathrm{~d}$ of each period based on daily individual cow records of TMR offered

Table 2. Ingredient and chemical composition (\% of DM unless otherwise noted) of dietary treatments with 2 levels of $\mathrm{CP}$ and 4 levels of tannins $(0,0.45,0.90$, and $1.80 \%$ of DM)

\begin{tabular}{|c|c|c|c|c|c|c|c|c|}
\hline \multirow[b]{2}{*}{ Item } & \multicolumn{4}{|c|}{$15.3 \% \mathrm{CP}$} & \multicolumn{4}{|c|}{$16.6 \% \mathrm{CP}$} \\
\hline & 0 & 0.45 & 0.90 & 1.80 & 0 & 0.45 & 0.90 & 1.80 \\
\hline \multicolumn{9}{|l|}{ Ingredient } \\
\hline Alfalfa silage & 27.8 & 27.8 & 27.8 & 27.8 & 27.7 & 27.7 & 27.7 & 27.7 \\
\hline Corn silage & 23.2 & 23.2 & 23.2 & 23.2 & 23.2 & 23.2 & 23.2 & 23.2 \\
\hline Premix low ${ }^{1}$ & 44.3 & 44.3 & 44.3 & 44.3 & - & - & - & - \\
\hline Premix high $^{2}$ & - & - & - & - & 44.4 & 44.4 & 44.4 & 44.4 \\
\hline Cottonseed & 2.9 & 2.9 & 2.9 & 2.9 & 2.9 & 2.9 & 2.9 & 2.9 \\
\hline Rice hulls & 1.8 & 1.35 & 0.9 & - & 1.8 & 1.35 & 0.9 & - \\
\hline Tannin extract & - & 0.45 & 0.9 & 1.8 & - & 0.45 & 0.9 & 1.8 \\
\hline \multicolumn{9}{|c|}{ Chemical composition } \\
\hline DM, \% & 50.2 & 50.1 & 49.0 & 49.2 & 49.4 & 50.8 & 50.1 & 49.8 \\
\hline $\mathrm{OM}$ & 92.3 & 92.4 & 92.5 & 92.6 & 92.4 & 92.4 & 92.5 & 92.6 \\
\hline $\mathrm{CP}$ & 15.3 & 15.3 & 15.3 & 15.3 & 16.5 & 16.6 & 16.6 & 16.5 \\
\hline $\mathrm{NDF}$ & 29.9 & 29.7 & 29.4 & 28.9 & 30.6 & 30.4 & 30.0 & 29.5 \\
\hline $\mathrm{NFC}^{3}$ & 45.2 & 45.0 & 44.7 & 44.2 & 43.5 & 43.3 & 42.9 & 42.5 \\
\hline Starch & 25.9 & 25.9 & 25.9 & 25.9 & 22.9 & 23.0 & 23.0 & 22.9 \\
\hline $\mathrm{RDP}^{4}$ & 9.8 & 9.8 & 9.8 & 9.8 & 10.3 & 10.4 & 10.4 & 10.4 \\
\hline $\mathrm{RUP}^{4}$ & 5.4 & 5.4 & 5.4 & 5.4 & 6.2 & 6.2 & 6.1 & 6.1 \\
\hline $\mathrm{NE}_{\mathrm{L}},{ }^{4} \mathrm{Mcal} / \mathrm{kg}$ & 1.58 & 1.59 & 1.59 & 1.59 & 1.60 & 1.59 & 1.61 & 1.62 \\
\hline
\end{tabular}

${ }^{1}$ Ingredient compositions (DM basis) for premix low: ground corn $56.7 \%$, solvent soybean meal 11.5\%, SoyPass $7.9 \%$ (LignoTech USA Inc., Rothschild, WI), roasted soybeans $8.8 \%$, soy hulls $8.8 \%$, calcium carbonate $1.8 \%$ sodium bicarbonate $1.8 \%$, magnesium oxide $0.4 \%$, monocalcium phosphate $0.4 \%$, Dynamate $0.2 \%$ (The Mosaic Co., Plymouth, MN), salt $1.1 \%$, vitamins $0.6 \%$.

${ }^{2}$ Ingredient composition (DM basis) for premix high: ground corn $50.7 \%$, solvent soybean meal $25.3 \%$, roasted soybeans $8.8 \%$, soy hulls $8.8 \%$, calcium carbonate $1.8 \%$, sodium bicarbonate $1.8 \%$, magnesium oxide $0.4 \%$, monocalcium phosphate $0.4 \%$, Dynamate $0.2 \%$ (The Mosaic Co.), salt $1.1 \%$, vitamins $0.6 \%$.

${ }^{3} \mathrm{NFC}=100-(\% \mathrm{NDF}+\% \mathrm{CP}+\%$ ether extract $+\%$ ash $)$, using tabular values for ether extract (NRC, 2001).

${ }^{4}$ Calculated using measured DMI, milk production, and composition and feed analyses (NRC, 2001). 
and refused and the $60^{\circ} \mathrm{C} \mathrm{DM}$ contents of the TMR and orts.

Ground feed samples were analyzed for total N (Leco FP-2000 Nitrogen Analyzer, Leco Instruments Inc., St. Joseph, MI), analytical DM at $105^{\circ} \mathrm{C}$ for $24 \mathrm{~h}$, ash (AOAC International, 2006; method 942.05), and NDF using $\alpha$-amylase (Sigma no. A3306, Sigma Chemical Co., St. Louis, MO) with sodium sulfite and corrected for ash concentration according to Van Soest et al. (1991), adapted for Ankom ${ }^{200}$ Fiber Analyzer (Ankom Technology, Fairport, NY). Nonfiber carbohydrate was calculated as $100-(\mathrm{NDF}+$ ether extract $+\mathrm{CP}+\mathrm{ash})$, where ether extract was from Table 15.1 of NRC (2001). Dietary ingredients from each period were pooled in a single sample and analyzed commercially for starch content (Dairyland Laboratories Inc., Arcadia, WI) using wet chemistry analysis (Bach-Knudsen, 1997). In addition, 30-h in vitro ruminal NDF digestibility and DM digestibility were determined in the pooled alfalfa silage (AS) and corn silage (CS) samples by the same commercial laboratory using the method of Goering and Van Soest (1970) with the modification that the inoculum was a composite containing strained ruminal fluid and blended ruminal solids. Chemical composition of the diets was computed from chemical composition and proportion of feed ingredients in the TMR.

Milk production of individual cows was recorded at each of the 2 daily milkings (0600 and $1600 \mathrm{~h}$ ) throughout the trial and summarized for the last $7 \mathrm{~d}$ of each period for statistical analysis of performance data. Milk samples from morning and evening milking were collected on d 18, 19, and 20 of each period and analyzed for fat, true protein, lactose, SNF, and MUN by infrared analysis (AgSource Milk Analysis Laboratory, Menomonie, WI) with a Foss FT6000 (Foss North America Inc., Eden Prairie, MN). Average daily concentration and yield of milk components were computed using morning and evening milk production as weighing factor. Yield of fat- and protein-corrected milk (FPCM) was calculated as milk $(\mathrm{kg} / \mathrm{d}) \times[0.1226 \times$ fat $(\%)+$ $0.0776 \times$ true protein $(\%)+0.2534]$ according to IDF (2010). Efficiencies of feed conversion were computed as the yields of milk and FPCM divided by DMI. In addition, efficiency of $\mathrm{N}$ utilization was calculated as milk $\mathrm{N}$ divided by $\mathrm{N}$ intake and as manure $\mathrm{N}$ (fecal $\mathrm{N}$ + urinary $\mathrm{N}$ ) divided by milk $\mathrm{N}$.

\section{Rumen Fermentation Pattern}

Eight lactating multiparous Holstein cows $(708 \pm 41$ $\mathrm{kg}$ of BW; $123 \pm 41$ DIM) fitted with ruminal cannulas were used to study ruminal fermentation pattern associated with the dietary treatments. A metal filter probe was used to sample fluid from 5 locations in the rumen to yield a $60-\mathrm{mL}$ composite sample from cows at 0 (prefeeding), $12,3,6,9,12$, and $18 \mathrm{~h}$ after feeding on d 18 of each period. Rumen $\mathrm{pH}$ was determined immediately after sample collection using a calibrated portable $\mathrm{pH}$ meter (Twin pH-meter Model B-213, Spectrum Technologies Inc., Plainfield, IL). One sub-sample of rumen fluid was acidified with $50 \% \mathrm{H}_{2} \mathrm{SO}_{4}$ and frozen until analysis for VFA by GLC (Perkin Elmer Autosystem, Norwalk, CT) as described by Bal et al. (2000), and a second rumen fluid sub-sample was mixed with $50 \%$ TCA and frozen until analysis for $\mathrm{NH}_{3}-\mathrm{N}$ (Chaney and Marbach, 1962).

\section{Total Fecal and Urine Collection, Sampling, and Analyses}

During d 19, 20, and 21 of each period, total collection of feces was performed on cannulated cows. The weight of feces, collected in pans fitted over the gutters, was recorded and sampled twice daily. Fecal samples were dried for $48 \mathrm{~h}$ at $60^{\circ} \mathrm{C}$, ground to $1 \mathrm{~mm}$, and analyzed for analytical DM, total N, and NDF content as described above. In addition, on d 19 to 21 total collection of urine was performed on the cannulated cows. Urine was collected using indwelling catheters into collection vessels containing $50 \% \mathrm{H}_{2} \mathrm{SO}_{4}$. Urine weight was recorded and samples collected twice daily and stored at $-20^{\circ} \mathrm{C}$. Urine samples were analyzed for total $\mathrm{N}$ (as described above) and urinary urea-N (Chaney and Marbach, 1962).

\section{Cow Body Weight and Blood Sampling}

Individual cow BW was once recorded at the beginning of the trial and once at the end of each period. Blood samples were collected into heparinized tubes 4 $\mathrm{h}$ after feeding from the coccygeal artery or vein of each cow on d 19 of each period and stored at $20^{\circ} \mathrm{C}$ until analyzes for BUN (Chaney and Marbach, 1962).

\section{Statistical Analysis}

Data were analyzed with the Mixed procedure in SAS (release 9.2, SAS Institute Inc., Cary, NC). Dry matter intake, milk yield, milk composition, and fecal and urine excretion and composition data were analyzed with the following model:

$$
\begin{gathered}
\mathrm{Y}_{\mathrm{ijkl}}=\mu+\mathrm{P}_{\mathrm{i}}+\mathrm{D}_{\mathrm{j}}+\mathrm{T}_{\mathrm{k}}+\mathrm{C}_{\mathrm{l}}+\mathrm{D}_{\mathrm{j}} \times \mathrm{T}_{\mathrm{k}} \\
+\mathrm{P}_{\mathrm{i}} \times \mathrm{D}_{\mathrm{j}}+\mathrm{e}_{\mathrm{ijk} \mathrm{k}},
\end{gathered}
$$


Table 3. Effect of tannin and dietary CP level on intake, milk production, milk composition, and BUN

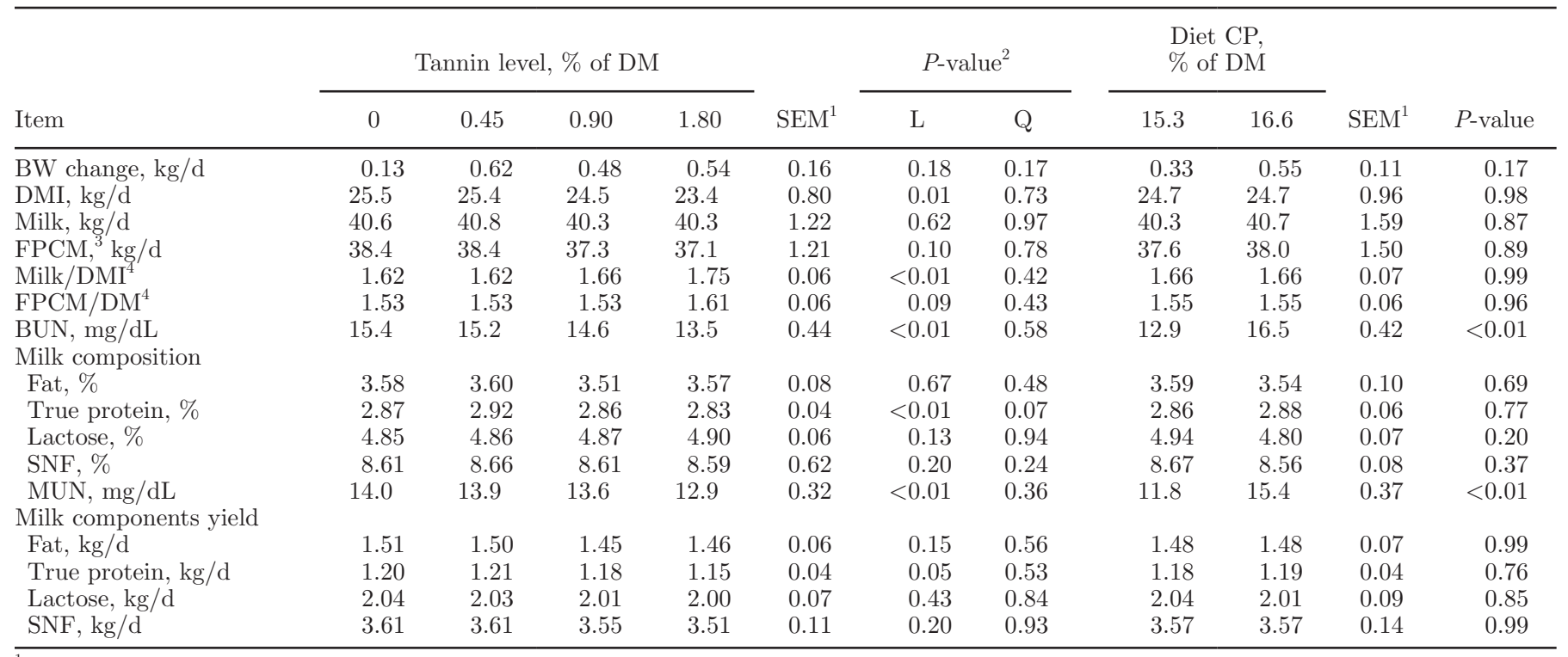

${ }^{1}$ Standard error of the mean (highest when uneven samples).

${ }^{2}$ Probability of a linear (L) or quadratic (Q) effect of tannin level in the diet.

${ }^{3}$ Fat- and protein-corrected milk $(\mathrm{FPCM})=\operatorname{milk}(\mathrm{kg} / \mathrm{d}) \times[0.1226 \times$ fat $(\%)+0.0776 \times$ true protein $(\%)+0.2534]($ IDF, 2010$)$.

${ }^{4}$ Efficiencies calculated as milk $(\mathrm{kg} / \mathrm{d})$ or FPCM $(\mathrm{kg} / \mathrm{d})$ divided by DMI $(\mathrm{kg} / \mathrm{d})$.

where $Y_{\mathrm{ijk}}$ is the dependent variable, $\mu$ is the overall mean, $\mathrm{P}_{\mathrm{i}}$ is the period effect (1 to 4$), \mathrm{D}_{\mathrm{j}}$ is the effect of $\operatorname{diet} \mathrm{CP}$ (1 to 2$), \mathrm{T}_{\mathrm{k}}$ is the effect of tannin (1 to 4$), \mathrm{C}_{1}$ is the effect of cow (within dietary $\mathrm{CP}$ ), $\mathrm{D}_{\mathrm{j}} \times \mathrm{T}_{\mathrm{k}}$ is the interaction effect between dietary $\mathrm{CP}$ and tannin, $\mathrm{P}_{\mathrm{i}} \times \mathrm{D}_{\mathrm{j}}$ is the interaction effect between period and dietary $\mathrm{CP}$, and $\mathrm{e}_{\mathrm{ijk}}$ is the residual error. All terms were considered fixed except for cow (within dietary $\mathrm{CP}$ ) and residual error, which were considered random.

The above model was expanded to include effect of time and interaction between dietary $\mathrm{CP}$ and tannin with time to analyze the repeated ruminal measurements $\left(\mathrm{pH}, \mathrm{NH}_{4}{ }^{+}-\mathrm{N}\right.$, and VFA). The spatial power covariance structure was used to fit a time series-type covariance structure in which the correlation declines as a function of time.

Pre-planned orthogonal contrasts were used to test for linear and quadratic effects of treatments. Significance was declared for $P \leq 0.05$ and tendency for 0.05 $<P \leq 0.10$. For repeated measurements, treatment differences at individual time points were assessed using the SLICE option when treatment $x$ time interactions were significant.

Variables showing quadratic effects that were significant at $P \leq 0.10$ were regressed on tannin concentration using the Mixed procedure of SAS to obtain intercept and linear and quadratic coefficients of the regression model. These equations were solved for tannin con- centrations at which these variables were maximal or minimal.

\section{RESULTS AND DISCUSSION}

One cow was removed from this experiment during the first period. Data collected from a replacement cow in periods 2, 3, and 4 were used in this study. For the measurements reported below (Tables 3 to 6 ), the interaction between dietary CP level and dietary tannin content did not reach significance $(P$-values ranged from 0.12 to 0.98 ), and therefore results will be presented as main effects of dietary $\mathrm{CP}$ and main effects of tannin.

\section{Dietary Ingredients and Treatments}

Chemical composition of diet ingredients are reported in Table 1. Based on CP and NDF values reported in Table 15.1 of NRC (2001), CS and AS used in this trial would be categorized as normal and mid-mature to mature, respectively. The relative proportion of dietary ingredients and chemical composition of the diets are reported in Table 2. As polyphenols were main contributions of tannin extracts to the diet, their increasing concentration in the diet had a limited effect on DM, OM, and NDF. Similarly, predicted RDP and RUP ( $\%$ of $\mathrm{DM}$ ) and diet $\mathrm{NE}_{\mathrm{L}}$ averaged $10.1 \%, 5.8 \%$, and 1.60 $\mathrm{Mcal} / \mathrm{kg}$, respectively, when computed on the basis of 
diet composition, feed analyses, and individual cow traits (BW and DIM) and performance (DMI, milk yield, and composition).

Dietary DM, OM, NDF and ether extract content were similar between CP levels and averaged 49.8, 92.5, 29.8, and $4.5 \%$ (DM basis), respectively. In contrast, as dietary CP increased from 15.3 to $16.6 \%$, starch decreased from 25.9 to $23.0 \%$ of dietary DM. Predicted RDP and RUP (\% of DM) and diet $\mathrm{NE}_{\mathrm{L}}$ were 9.8 versus $10.4 \%, 5.4$ versus $6.1 \%$, and 1.59 versus $1.61 \mathrm{Mcal} / \mathrm{kg}$ for the 15.3 versus $16.6 \% \mathrm{CP}$ diets, respectively. Predicted MP (NRC, 2001) slightly exceeded the requirements by $1.6 \%$ on the $16.6 \% \mathrm{CP}$ diet but was $4.8 \%$ deficient in the $15.3 \% \mathrm{CP}$ diet.

\section{Feed Intake and Performance}

Tannin Level. A linear decrease in DMI was found, as well as a linear increase in milk/DMI, and a trend for a linear decrease in FPCM and FPCM/DMI in response to tannin supplementation (Table 3). In addition, a linear decrease in DMI and a linear increase in milk/DMI were observed with increasing level of tannin. In general, short-term studies have shown little effect of adding quebracho or chestnut tannin extract to the diet on DMI and milk production. Benchaar et al. (2008) and Liu et al. (2013) found that quebracho or chestnut tannins did not affect DMI or milk production of lactating cows when fed at 0.45 or $1 \%$ of diet DM, respectively. Similarly, Sliwinski et al. (2004) reported no effect on feed intake and milk production when chestnut tannin was included at $0.49 \%$ of dietary DM.
However, Dschaak et al. (2011) observed that adding quebracho tannin at $3 \%$ of diet DM decreased both DMI and milk/DMI of lactating cows but not milk production. Thus, based on the literature, the negative effect of the tannin extract on DMI at the levels used in this trial was unexpected and the reasons for which it occurred remain unclear.

Milk fat, lactose, and SNF content (\%) and yield $(\mathrm{kg} / \mathrm{d})$ were not affected by tannin addition (Table 3 ). Based on the observed quadratic response, the maximal milk protein concentration was predicted to be $2.89 \%$ with a tannin concentration of $0.47 \%$. However, milk protein yield declined linearly with levels of tannin. Thus, the beneficial effect of some dietary tannin on milk protein concentration did not translate into higher milk protein yield. Several authors (Sliwinski et al., 2004; Benchaar et al., 2008; Dschaak et al., 2011) have reported no changes in milk component concentration and yield when quebracho or chestnut tannins were added to the diet.

Milk urea nitrogen and BUN decreased linearly when tannin content in the diet was increased from 0 to $1.80 \%$ of DM. Other authors have shown a similar response to tannin addition that reflects lower rumen protein degradation (Dschaak et al., 2011).

Dietary $\boldsymbol{C P}$. Increasing dietary CP content from 15.3 to 16.6 to \% DM did not influence BW gain, DMI, milk yield, FPCM, feed efficiency, and milk composition and yield (Table 3). These results are consistent with a short-term study (Olmos Colmenero and Broderick, 2006) where dietary CP was reduced from 19.4 to $15.0 \%$ of dietary DM. However, Broderick (2003)

Table 4. Effect of tannin and dietary CP level on concentration of ruminal metabolites

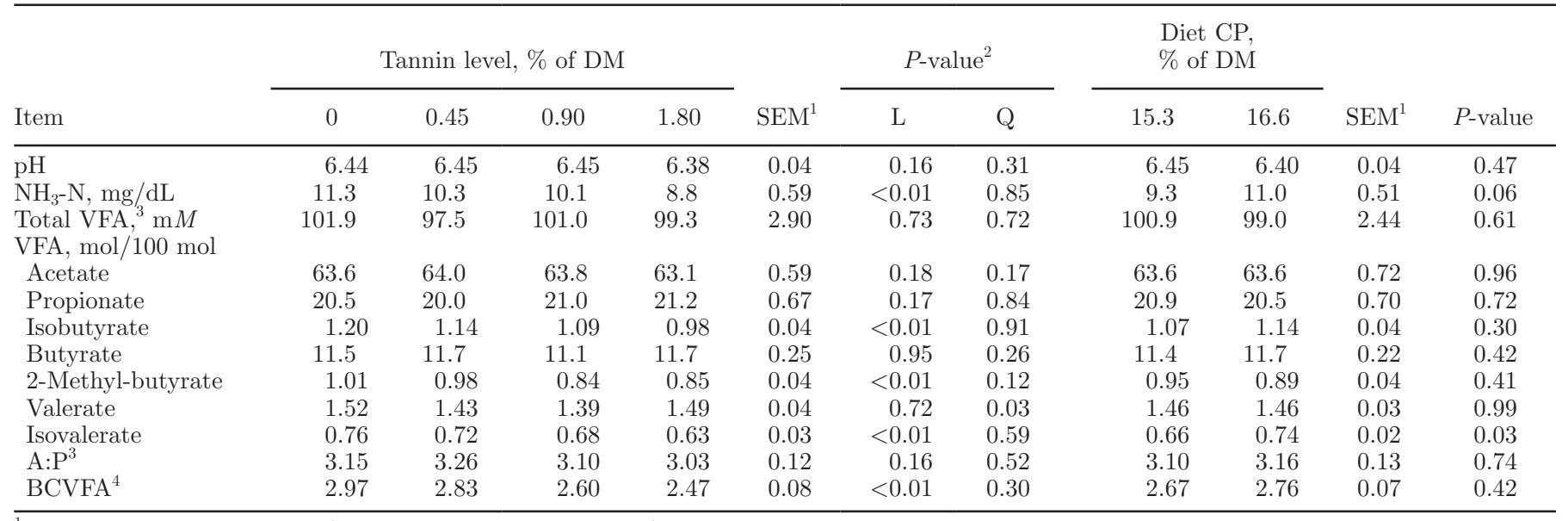

${ }^{1}$ Standard error of the mean (highest when uneven samples).

${ }^{2}$ Probability of a linear (L) or quadratic (Q) effect of tannin level in the diet.

${ }^{3}$ Acetate to propionate ratio.

${ }^{4}$ Branched-chain fatty acids (isobutyrate +2 -methyl-butyrate + isovalerate). 
Table 5. Effect of tannin content and dietary CP level on intake and total-tract apparent digestibility

\begin{tabular}{|c|c|c|c|c|c|c|c|c|c|c|c|}
\hline \multirow[b]{2}{*}{ Item } & \multicolumn{4}{|c|}{ Tannin level, $\%$ of DM } & \multirow[b]{2}{*}{$\mathrm{SEM}^{1}$} & \multicolumn{2}{|c|}{$P$-value ${ }^{2}$} & \multicolumn{2}{|c|}{$\begin{array}{l}\text { Diet CP, } \\
\% \text { of DM }\end{array}$} & \multirow[b]{2}{*}{$\mathrm{SEM}^{1}$} & \multirow[b]{2}{*}{$P$-value } \\
\hline & 0 & 0.45 & 0.90 & 1.80 & & L & Q & 15.3 & 16.6 & & \\
\hline DM & 23.3 & 23.7 & 23.8 & 22.1 & 0.78 & 0.15 & 0.14 & 24.1 & 22.3 & 0.82 & 0.16 \\
\hline OM & 21.5 & 21.9 & 22.0 & 20.5 & 0.72 & 0.17 & 0.13 & 22.3 & 20.6 & 0.77 & 0.17 \\
\hline CP & 3.7 & 3.7 & 3.8 & 3.5 & 0.12 & 0.19 & 0.12 & 3.7 & 3.7 & 0.13 & 0.98 \\
\hline DM & 66.2 & 65.6 & 64.2 & 61.5 & 0.88 & $<0.01$ & 0.55 & 62.6 & 66.1 & 0.85 & 0.03 \\
\hline OM & 68.1 & 67.6 & 66.0 & 63.2 & 0.81 & $<0.01$ & 0.48 & 64.3 & 68.2 & 0.81 & 0.02 \\
\hline $\mathrm{CP}$ & 63.4 & 60.8 & 59.3 & 54.1 & 1.16 & $<0.01$ & 0.75 & 55.9 & 62.9 & 1.19 & 0.01 \\
\hline NDF & 49.4 & 49.6 & 46.0 & 43.6 & 1.90 & 0.01 & 0.90 & 45.5 & 48.8 & 2.02 & 0.29 \\
\hline
\end{tabular}

${ }^{1}$ Standard error of the mean (highest when uneven samples).

${ }^{2}$ Probability of a linear (L) or quadratic (Q) effect of tannin level in the diet.

reported a decrease in DMI and milk yield when dietary CP was decreased from 16.7 to $15.1 \%$. Chen et al. (2011) reported that compared with a $16.8 \% \mathrm{CP}$ diet, feeding $15.6 \% \mathrm{CP}$ for $12 \mathrm{wk}$ had no effect on DMI or milk yield, but reduced FCM yield.

Although in the current study, the $15.3 \% \mathrm{CP}$ diet did not meet NRC (2001) predicted MP requirements (4.8\% deficient), a meta-analysis by Huhtanen and Hristov (2009) suggested that the current NRC (2001) prediction model overestimates MP requirements of dairy cows. Furthermore, in a recent review of the literature, Hristov and Giallongo (2014) indicated that diets with MP deficiencies greater than $12 \%$ may penalize milk production, partially through decreased DMI.
A decrease in MUN concentration was observed when feeding the $15.3 \%$ diet. The same response to dietary $\mathrm{CP}$ level was observed on BUN. These results are consistent with previous studies that have shown a close correlation between dietary CP, BUN, and MUN (Broderick and Clayton, 1997).

\section{Rumen Measurements}

Tannin Level. Tannin supplementation did not influence ruminal $\mathrm{pH}$, total VFA concentration, molar proportions of acetate, propionate, butyrate, and acetate-to-propionate ratio (A:P), but was effective in reducing ruminal $\mathrm{NH}_{3}-\mathrm{N}$ concentration and molar

Table 6. Effect of tannin content and dietary CP level on $\mathrm{N}$ utilization and manure excretion

\begin{tabular}{|c|c|c|c|c|c|c|c|c|c|c|c|}
\hline \multirow[b]{2}{*}{ Item } & \multicolumn{4}{|c|}{ Tannin level, \% of DM } & \multirow[b]{2}{*}{ SEM } & \multicolumn{2}{|c|}{$P$-value ${ }^{1}$} & \multicolumn{2}{|c|}{$\begin{array}{l}\text { Diet CP, } \\
\% \text { of DM }\end{array}$} & \multirow[b]{2}{*}{ SEM } & \multirow[b]{2}{*}{$P$-value } \\
\hline & 0 & 0.45 & 0.90 & 1.80 & & $\mathrm{~L}$ & Q & 15.3 & 16.6 & & \\
\hline $\mathrm{N}$ intake, $\mathrm{g} / \mathrm{d}$ & 586 & 598 & 603 & 561 & 19.9 & 0.19 & 0.12 & 587 & 588 & 21.2 & 0.98 \\
\hline Milk N, g/d & 174 & 177 & 177 & 170 & 9.5 & 0.32 & 0.23 & 191 & 158 & 12.7 & 0.12 \\
\hline Milk N/N intake & 0.30 & 0.30 & 0.29 & 0.30 & 2.0 & 0.56 & 0.42 & 0.33 & 0.27 & 1.7 & 0.05 \\
\hline \multicolumn{12}{|l|}{ Urine excretion } \\
\hline Urine output, kg/d & 30.8 & 30.5 & 30.9 & 28.5 & 1.3 & 0.02 & 0.17 & 29.5 & 30.9 & 1.6 & 0.57 \\
\hline Urine $\mathrm{N}, \mathrm{g} / \mathrm{d}$ & 213 & 201 & 207 & 179 & 7.2 & $<0.01$ & 0.30 & 168 & 232 & 7.5 & $<0.01$ \\
\hline Urine $\mathrm{N}, \%$ of $\mathrm{N}$ intake & 36.3 & 33.8 & 34.5 & 31.6 & 1.5 & 0.04 & 0.95 & 28.7 & 39.4 & 1.4 & $<0.01$ \\
\hline Urea-N, g/d & 141 & 134 & 136 & 116 & 6.1 & $<0.01$ & 0.26 & 100 & 164 & 7.0 & $<0.01$ \\
\hline Urea-N, \% urine $\mathrm{N}$ & 64.7 & 65.6 & 65.1 & 63.7 & 1.0 & 0.16 & 0.17 & 59.0 & 70.6 & 1.2 & $<0.01$ \\
\hline \multicolumn{12}{|l|}{ Fecal excretion } \\
\hline Fecal output, kg/d & 53.3 & 56.8 & 59.5 & 58.4 & 2.5 & 0.01 & 0.02 & 63.2 & 50.8 & 3.2 & 0.03 \\
\hline $\mathrm{DM}, \mathrm{kg} / \mathrm{d}$ & 7.8 & 8.1 & 8.5 & 8.5 & 0.3 & 0.01 & 0.11 & 9.0 & 7.5 & 0.4 & 0.06 \\
\hline Fecal N, g/d & 214 & 234 & 245 & 256 & 10.1 & $<0.01$ & 0.07 & 257 & 217 & 13.0 & 0.07 \\
\hline Fecal N, \% of N intake & 36.6 & 39.2 & 40.7 & 45.9 & 1.2 & $<0.01$ & 0.75 & 44.1 & 37.1 & 1.2 & $<0.01$ \\
\hline \multicolumn{12}{|l|}{ Manure excretion } \\
\hline Manure output, kg/d & 84.1 & 87.3 & 90.4 & 86.9 & 3.1 & 0.19 & 0.01 & 92.7 & 81.6 & 4.1 & 0.11 \\
\hline Manure $\mathrm{N},{ }^{2} \mathrm{~g} / \mathrm{d}$ & 427 & 436 & 452 & 434 & 14.0 & 0.50 & 0.07 & 425 & 449 & 17.3 & 0.38 \\
\hline
\end{tabular}

${ }^{1}$ Probability of a linear (L) or quadratic (Q) effect of tannin level in the diet.

${ }^{2}$ Manure $\mathrm{N}(\mathrm{g} / \mathrm{d})=$ urinary $\mathrm{N}$ output $(\mathrm{g} / \mathrm{d})+$ fecal $\mathrm{N}$ output $(\mathrm{g} / \mathrm{d})$. 
proportion of branched-chain VFA (Table 4). Benchaar et al. (2008) reported that total concentrations of VFA and molar proportions of individual VFA were not affected by feeding quebracho tannin extracts at $0.64 \%$ of diet DM. In contrast, Beauchemin et al. (2007) reported that increasing supplementation levels of quebracho tannins up to $2 \%$ of DMI tended to decrease ruminal total VFA concentration, and decreased acetate molar proportion and A:P ratio. Similarly, Dschaak et al. (2011) found a reduction in total VFA concentration regardless of level of forage when quebracho tannin extracts were supplemented at $3 \%$ of diet DM. However, the authors reported an interaction between forage level and tannin supplementation on molar proportions of acetate, propionate, and butyrate. The contradictory results observed on total VFA concentration and VFA patterns seem to be associated with tannin supplementation level, tannin sources, the associative effect between tannin and diet composition, and rumen microbe adaptation time to tannins (Makkar, 2003).

Several studies have shown that feeding of chestnut (Sliwinski et al., 2002) and quebracho (Dawson et al., 1999; Frutos et al., 2004; Getachew et al., 2008) tannin extracts reduced $\mathrm{NH}_{3}-\mathrm{N}$ concentration in ruminal fluid as a result of a lower ruminal protein degradation likely due to the formation of tannin-protein complexes. Furthermore, the linear reduction in branched-chain VFA observed in the present study is consistent with a decrease in AA deamination.

Dietary $\boldsymbol{C P}$. Increasing dietary $\mathrm{CP}$ had no effect on ruminal $\mathrm{pH}$, total VFA concentration, molar proportions of acetate, propionate, butyrate, branched-chain VFA, and A:P ratio, but increased ruminal $\mathrm{NH}_{3}-\mathrm{N}$ concentration. Increased ruminal $\mathrm{NH}_{3}-\mathrm{N}$ concentration with increase dietary $\mathrm{CP}$ have been frequently reported in the literature (Olmos Colmenero and Broderick, 2006; Broderick et al., 2008).

\section{Apparent Total-Tract Digestibility}

Tannin Level. Table 5 summarizes apparent digestibility measurements collected during the last $3 \mathrm{~d}$ of each period from cannulated cows $(n=8)$. Intakes of $\mathrm{DM}, \mathrm{OM}$, and $\mathrm{CP}$ were similar among dietary tannin levels. However, NDF intake decreased linearly with increasing level of tannin in the diet (Table 5). Dry matter, OM, CP, and NDF digestibility (\% DM) decreased linearly with increasing levels of dietary tannin. These results were consistent with other studies that had also reported lower nutrient digestibility when quebracho was added to the diet (Dawson et al., 1999; Ahnert et al., 2015). The strong binding affinity of tannins for protein relative to other substrates is demonstrated by the higher reduction in $\mathrm{CP}$ apparent digestibility compared with DM, OM, and NDF. In addition, a decreased digestibility of dietary feed fractions, especially of fiber, will likely slow digesta clearance from the rumen, resulting in a DMI reduction as observed in the current trial (Table 3).

In this study, dietary tannin extracts protected dietary protein from rumen degradation as confirmed by the lower rumen $\mathrm{NH}_{3}-\mathrm{N}$, branched-chain VFA, and BUN concentrations (Tables 3 and 4), which likely resulted in an increase of feed protein flow to the intestine. However, it may have reduced also ruminal microbial activity, which resulted in a lower digestibility of feed fractions (DM, OM, and NDF) and overall microbial outflow. Furthermore, undissociated tannins bound to either bacterial or dietary protein may reduce intestinal enzyme access (Waghorn, 2008). In addition, even if the tannin-protein complex is completely reversible in the abomasum, dissociate tannin may bind to feed protein and endogenous enzyme in the intestine, decreasing overall protein availability (Silanikoveetal., 1994; Waghorn, 2008). Thus, the net balance between an increase of feed protein flow to the intestine from the rumen and a reduction in MP availability in the intestine would determine the beneficial effects of the tannins (Makkar, 2003). Results from this study suggest small beneficial effects at low tannin levels (milk protein content), but detrimental effects at higher levels of tannin inclusion as indicated by the lower milk protein content and yield (Table 3) and overall apparent nutrient digestibility (Table 5).

Although a reduction on microbial activity cannot be discarded, the decrease in NDF digestibility results should be interpreted with caution as condensed tannin can bind to fiber fractions and thus increase fecal NDF values (Makkar, 2003).

Dietary $\boldsymbol{C P}$. Intakes of DM, OM, CP, and NDF were similar between dietary CP levels (Table 5). However, apparent digestibility of DM, OM, and $\mathrm{CP}$ were $3.5,3.9$, and 7.0 percentage units lower, and apparent digestibility of NDF was numerically 3.3 percentage units lower for $15.3 \%$ CP compared with $16.6 \% \mathrm{CP}$.

Results were consistent with decreased apparent digestibility of DM, OM, and NDF when dietary $\mathrm{CP}$ and RDP were decreased below 16 and $10 \%$ of dietary DM, respectively (Broderick et al., 2009; Hristov and Giallongo, 2014). Furthermore, Belanche et al. (2012) reported that a reduction in the dietary protein level from 110 to $80 \%$ of the $\mathrm{N}$ requirements resulted in a lower diet digestibility, likely associated with the observed decrease in the rumen microbial diversity, abundance of total bacteria, anaerobic fungi, methanogens, and cellulolytic bacteria. 
Interestingly, this decrease in nutrient apparent digestibility did not affect milk yield, milk composition, or yield most likely due to the lack of treatment response on DMI. In a recent review, Hristov and Giallongo (2014) indicated that a decrease in milk production occurred primarily when dietary treatments with low protein and MP-deficient diets reduced DMI.

The increase in apparent CP digestibility when cows were fed the $16.6 \% \mathrm{CP}$ diet is likely the result of a dilution of metabolic fecal $\mathrm{N}$ as well as the effect of greater intake of soybean meal, a highly digestible protein source (Broderick, 2003).

\section{Fecal and Urine Excretion and N Excretion (Cannulated Cows)}

Tannin Level. Dietary tannin had no effect on N intake $(587 \pm 63 \mathrm{~g} / \mathrm{d})$, milk N $(175 \pm 32 \mathrm{~g} / \mathrm{d})$ or N utilization efficiency ( $29.7 \pm 4.4 \%$; Table 6$)$. However, feeding tannin extracts linearly increased both wet and dry fecal $(\mathrm{kg} / \mathrm{d})$ output and fecal $\mathrm{N}$ excretion, but reduced urinary $\mathrm{N}$ and urinary urea $\mathrm{N}$ excretion. Dietary tannin inclusion also had a quadratic effect on fecal output (maximum of $59.8 \mathrm{~kg} / \mathrm{d}$ at a tannin level of $1.24 \%$ of dietary DM) and fecal $\mathrm{N}$ excretion (maximum of $256 \mathrm{~g} / \mathrm{d}$ at a tannin level of $1.77 \%$ of dietary DM). The shift in $\mathrm{N}$ partitioning from urine to feces with incremental levels of tannins has been reported in several studies with tannin extracts from quebracho (Dawson et al., 1999; Ahnert et al., 2015). The exact origin of the incremental fecal $\mathrm{N}$ when some tannins are added to the diet has not been well established and may reflect the excretion of postruminal undissociated tannin-protein complexes or the rebind of dissociated tannins to feed proteins and endogenous proteins secreted in the intestine (Makkar, 2003; Mueller-Harvey, 2006). The decrease in urinary N and urinary urea $\mathrm{N}$ excretion was likely associated with the protein binding properties of tannins that resulted in lower ruminal protein degradation (see above). Although the exact mechanism remains unclear, tannins lowered the amount of $\mathrm{N}(\mathrm{g} / \mathrm{d})$ and the percentage of intake $\mathrm{N}$ lost in urine. Increasing tannin extracts in the diet resulted in quadratic responses for manure output (maximum of $90.0 \mathrm{~kg} / \mathrm{d}$ at a tannin level of $1.06 \%$ of dietary $\mathrm{DM}$ ), and manure $\mathrm{N}$ excretion (maximum of $448 \mathrm{~g} / \mathrm{d}$ at a tannin level of $1.02 \%$ dietary DM). The quadratic response on manure $\mathrm{N}$ was likely the result of a quadratic response for fecal $\mathrm{N}$ and a negative linear response for urine $\mathrm{N}$ excretion.

Results from this study suggest that tannin extracts could reduce manure $\mathrm{NH}_{3}$ emission because urinary $\mathrm{N}$ is much more vulnerable to environmental losses than fecal N. This hypothesis was confirmed in a follow-up study, in which 48-h of cumulative $\mathrm{NH}_{3}$ emission was reduced on average by 12 and $19 \%$ when feces and urine obtained in the present study were applied to simulated barn floors or incubated soils, respectively (Powell et al., 2011a,b). In agreement with our observations, Sliwinski et al. (2004) reported a decrease in $\mathrm{N}$ losses over an 8-wk period of manure storage when lactating dairy cows were fed tannins obtained from chestnut extracts $(0.50 \%$ diet $\mathrm{DM})$. Larger-scale studies are required to determine the effectiveness of tannin extracts in abating $\mathrm{NH}_{3}$ loss from dairy barn floors and land-applied manure.

Dietary $\boldsymbol{C P}$. A $1.3 \%$ unit reduction in dietary CP increased $\mathrm{N}$ utilization efficiency (milk $\mathrm{N} / \mathrm{N}$ intake) from 0.27 to 0.33 and decreased urinary $\mathrm{N}$ excretion by $28 \%$ (232 vs. $168 \mathrm{~g} / \mathrm{d}$ for 15.3 and $16.6 \% \mathrm{CP}$, respectively). Almost all the additional N (64 g/d per cow) excreted in the $16.6 \% \mathrm{CP}$ diet relative to the amount excreted in the $15.3 \% \mathrm{CP}$ diet was in the form of urea $\mathrm{N}$, most likely the result of higher rumen protein degradation as indicated by an increase in rumen $\mathrm{NH}_{3}-\mathrm{N}$, BUN, and MUN concentrations when cows were fed the 16.6\% CP diet (Tables 3 and 4). The higher fecal (wet and DM basis) output and fecal $\mathrm{N}$ excretion observed on the 15.3 versus $16.6 \% \mathrm{CP}$ diet are consistent with the lower apparent digestibility reported in Table 5 .

Although manure $\mathrm{N}$ (fecal $\mathrm{N}+$ urinary $\mathrm{N}$ ) remained unaltered, the reduction in urine $\mathrm{N}$ and urine urea$\mathrm{N}$ when dietary $\mathrm{CP}$ was reduced from 16.6 to $15.3 \%$ suggests that manure $\mathrm{N}$ from cows fed the $15.3 \% \mathrm{CP}$ diet might be less vulnerable to $\mathrm{NH}_{3}$ volatilization. A reduction in dietary $\mathrm{CP}$ decreased emission of $\mathrm{NH}_{3}$ from manure under laboratory conditions (Powell et al., 2011a; Lee et al., 2012) as well as under farm conditions (Aguerre et al., 2010). Furthermore, when applied to soil and incubated in laboratory-scale ventilated chambers, manure obtained from the $16.6 \% \mathrm{CP}$ treatment emitted 2.16 times more $\mathrm{NH}_{3}$ than manure from the $15.3 \%$ CP treatment (Powell et al., 2011b).

\section{CONCLUSIONS}

Regardless of dietary CP content, increasing levels of a tannin extract mixture from quebracho and chestnut in the diet had negative effects on DMI, FPCM, milk true protein content and yield, and nutrient apparent digestibility, in particular when fed at 0.90 and $1.80 \%$ of diet DM. However, maximum predicted milk true protein content was observed when tannins were fed at a level of $0.45 \%$ diet DM. In addition, increasing the tannin extract mix in the diet reduced ruminal protein degradation, decreased the amount of $\mathrm{N}$ excreted in the urine (more vulnerable to environmental loss), and 
increased fecal $\mathrm{N}$ (more resilient to environmental loss). Feeding a quebracho and chestnut tannin extract at $0.45 \%$ of diet DM may be adequate to reduce excretion of environmental labile urinary $\mathrm{N}$ with a small effect on animal performance. However, higher levels of inclusion will penalize production and nutrient digestibility. Further research is warranted to confirm this result in a long-term feeding study evaluating potential microbial adaptation. Results of this trial indicated that compared with a $16.6 \% \mathrm{CP}$ (MP-adequate) diet, feeding a $15.3 \%$ CP (4.8\% MP-deficient) diet over a 12 -wk period did not affect DMI and was adequate for supporting milk production, despite a reduction in DM, OM, and NDF apparent digestibility. In addition, decreasing dietary $\mathrm{CP}$ reduced urinary $\mathrm{N}$ excretion and improved $\mathrm{N}$ utilization efficiency.

\section{ACKNOWLEDGMENTS}

The authors thank Jerry Guenther and his barn crew for feeding and animal care at the University of Wisconsin-Madison Dairy Cattle Center; Sandra Bertics (University of Wisconsin-Madison, Dairy Science Department), Wendy Radloff, and Mary Becker (US Dairy Forage Research Center, Madison, WI) for assisting with laboratory analyses; Jacob Finer, Teresa Kaiser, and other University of Wisconsin-Madison students for helping during sample collection and processing; and SilvaTeam, Indunor, S.A, Argentina, for financial support and for donating the Bypro extract.

\section{REFERENCES}

Aguerre, M. J., T. Hunt, B. R. Larget, and M. A. Wattiaux. 2010. Effect of dietary crude protein on ammonia-N loss measured by herd nitrogen mass balance in a freestall dairy barn under Wisconsin farm-like conditions. Animal 4:1390-1400.

Ahnert, S., U. Dickhoefer, F. Schulz, and A. Susenbeth. 2015. Influence of ruminal Quebracho tannin extract infusion on apparent nutrient digestibility, nitrogen balance, and urinary purine derivatives excretion in heifers. Livest. Sci. 177:63-70.

AOAC International. 2006. Official Methods of Analysis. Vol. I. 15th ed. AOAC Int., Arlington, VA.

Bach-Knudsen, K. E. 1997. Carbohydrate and lignin contents of plant materials used in animal feeding. Anim. Feed Sci. Technol. 67:319 338 .

Bal, M. A., R. D. Shaver, A. G. Jirovec, K. J. Shinners, and J. G. Coors. 2000. Crop processing and chop length of corn silage: Effects on intake, digestion, and milk production by dairy cows. J. Dairy Sci. 83:1264-1273.

Beauchemin, K. A., S. M. McGinn, T. F. Martinez, and T. A. McAllister. 2007. Use of condensed tannin extract from quebracho trees to reduce methane emissions from cattle. J. Anim. Sci. 85:1990-1996.

Belanche, A., M. Doreau, J. E. Edwards, J. M. Moorby, E. Pinloche, and C. J. Newbold. 2012. Shifts in the rumen microbiota due to the type of carbohydrate and level of protein ingested by dairy cattle are associated with changes in rumen fermentation. J. Nutr. 142:1684-1692.

Benchaar, C., T. A. McAllister, and P. Y. Chouinard. 2008. Digestion, ruminal fermentation, ciliate protozoal populations, and milk production from dairy cows fed cinnamaldehyde, quebracho condensed tannin, or Yucca schidigera saponin extract. J. Dairy Sci. 91:4765-4777.

Broderick, G. A. 2003. Effects of varying dietary protein and energy levels on the production of lactating dairy cows. J. Dairy Sci. 86:1370-1381.

Broderick, G. A., and M. K. Clayton. 1997. A statistical evaluation or animal and nutritional factors influencing concentrations or milk urea nitrogen. J. Dairy Sci. 80:2964-2971.

Broderick, G. A., M. J. Stevenson, and R. A. Patton. 2008. Effect of supplementing rumen-protected methionine on production and nitrogen excretion in lactating dairy cows. J. Dairy Sci. 91:10921102 .

Broderick, G. A., M. J. Stevenson, and R. A. Patton. 2009. Effect of dietary protein concentration and degradability on response to rumen-protected methionine in lactating dairy cows. J. Dairy Sci. 92:2719-2728.

Chaney, A. L., and E. P. Marbach. 1962. Modified reagents for determination of urea and ammonia. Clin. Chem. 8:130-132.

Chen, Z. H., G. A. Broderick, N. D. Luchini, B. K. Sloan, and E. Devillard. 2011. Effect of feeding different sources of rumen-protected methionine on milk production and N-utilization in lactating dairy cows. J. Dairy Sci. 94:1978-1988.

Dawson, J. M., P. J. Buttery, D. Jenkins, C. D. Wood, and M. Gill. 1999. Effects of dietary quebracho tannin on nutrient utilization and tissue metabolism in sheep and rats. J. Sci. Food Agric. 79:1423-1430.

Dschaak, C. M., C. M. Williams, M. S. Holt, J.-S. Eun, A. J. Young, and B. R. Min. 2011. Effects of supplementing condensed tannin extract on intake, digestion, ruminal fermentation, and milk production of lactating dairy cows. J. Dairy Sci. 94:2508-2519.

Frutos, P., G. Hervas, F. J. Giraldez, and A. R. Mantecon. 2004. An in vitro study on the ability of polyethylene glycol to inhibit the effect of quebracho tannins and tannic acid on rumen fermentation in sheep, goats, cows, and deer. Aust. J. Agric. Res. 55:1125-1132.

Getachew, G., W. Pittroff, D. H. Putnam, A. Dandekar, S. Goyal, and E. J. DePeters. 2008. The influence of addition of gallic acid, tannic acid, or quebracho tannins to alfalfa hay on in vitro rumen fermentation and microbial protein synthesis. Anim. Feed Sci. Technol. 140:444-461.

Goering, H. K., and P. J. Van Soest. 1970. Forage fiber analysis. USDA Agric. Handbook No. 379. USDA-ARS, Washington, DC

Hristov, A. N., and F. Giallongo. 2014. Feeding Protein to Dairy Cows-What Should Be Our Target? Tri-State Dairy Nutrition Conference. Pages 75-84 in Tri-State Dairy Nutrition Conference Proceedings, Fort Wayne, IN.

Huhtanen, P., and A. N. Hristov. 2009. A meta-analysis of the effects of protein concentration and degradability on milk protein yield and milk N efficiency in dairy cows. J. Dairy Sci. 92:3222-3232.

International Dairy Federation (IDF). 2010. A common carbon footprint approach for dairy: The IDF guide to standard lifecycle assessment methodology for the dairy sector. Bull. Int. Dairy Fed. 445 Brussels, Belgium.

Komolong, M. K., D. G. Barber, and D. M. McNeill. 2001. Postruminal protein supply and $\mathrm{N}$ retention of weaner sheep fed on a basal diet of lucerne hay (Medicago sativa) with increasing levels of quebracho tannins. Anim. Feed Sci. Technol. 92:59-72.

Lee, C., A. N. Hristov, C. J. Dell, G. W. Feyereisen, J. Kaye, and D. Beegle. 2012. Effect of dietary protein concentration on ammonia and greenhouse gas emitting potential of dairy manure. J. Dairy Sci. 95:1930-1941.

Liu, H. W., D. W. Zhou, and K. Li. 2013. Effects of chestnut tannins on performance and antioxidative status of transition dairy cows. J. Dairy Sci. 96:5901-5907.

Makkar, H. P. S. 2003. Effects and fate of tannins in ruminant animals, adaptation to tannins, and strategies to overcome detrimental effects of feeding tannin-rich feeds. Small Rumin. Res. 49:241-256.

Muck, R. E., and B. K. Richards. 1983. Losses of manurial nitrogen in free-stall barns. Agricultural Wastes 7:65-79.

Mueller-Harvey, I. 2006. Unravelling the conundrum of tannins in animal nutrition and health. J. Sci. Food Agric. 86:2010-2037. 
NRC. 2001. Nutrient Requirements of Dairy Cattle. 7th rev. ed. Natl. Acad. Press, Washington, DC.

Olmos Colmenero, J. J., and G. A. Broderick. 2006. Effect of dietary crude protein concentration on milk production and nitrogen utilization in lactating dairy cows. J. Dairy Sci. 89:1704-1712.

Pizzi, A., H. Pasch, K. Rode, and S. Giovando. 2009. Polymer structure of commercial hydrolysable tannins by matrix assisted laser desorption ionization time of flight mass spectrometry. J. Appl. Polym. Sci. 113:3847-3859.

Powell, J. M., M. J. Aguerre, and M. A. Wattiaux. 2011a. Tannin extracts abate ammonia emissions from simulated dairy barn floors. J. Environ. Qual. 40:907-914.

Powell, J. M., M. J. Aguerre, and M. A. Wattiaux. 2011b. Dietary crude protein and tannin impact dairy manure chemistry and ammonia emissions from incubated soils. J. Environ. Qual. 40:17671774.

Silanikove, N., Z. Nitsan, and A. Perevolotsky. 1994. Effect of a daily supplementation of polyethylene glycol on intake and digestion of tannin-containing leaves (Ceratonia siliqua) by sheep. J. Agric. Food Chem. 42:2844-2847.

Sliwinski, B. J., M. Kreuzer, F. Sutter, A. Machmuller, and H. R. Weststein. 2004. Performance, body nitrogen conversion and nitrogen emission from manure of dairy cows fed diets supplemented with different plant extracts. J. Anim. Feed Sci. 13:73-91.

Sliwinski, B. J., C. R. Soliva, A. Machmuller, and M. Kreuzer. 2002 Efficacy of plant extracts rich in secondary constituents to modify rumen fermentation. Anim. Feed Sci. Technol. 101:101-114.

Van Soest, P. J., J. B. Robertson, and B. A. Lewis. 1991. Methods for dietary fiber, neutral detergent fiber, and non-starch polysaccharides in relation to animal nutrition. J. Dairy Sci. 74:3583-3597.

Waghorn, G. 2008. Beneficial and detrimental effects of dietary condensed tannins for sustainable sheep and goat production-Progress and challenges. Anim. Feed Sci. Technol. 147:116-139. 